\title{
PENGARUH PENERAPAN PEMBELAJARAN KOOPERATIF TIPE STAD TERHADAP KEMAMPUAN PEMECAHAN MASALAH MATEMATIKA
}

\author{
NURUL AULIA DEWI ${ }^{1)}$, MUHAMMAD IRHAM ${ }^{2)}$, SARWO EDY WIBOWO ${ }^{3)}$ \\ Program Studi Pendidikan Matematika STKIP Paracendekia NW Sumbawa
}

e-mail: sarwoedyumm@gmail.com

\begin{abstract}
ABSTRAK
Penelitian ini bertujuan untuk mengetahui pengaruh model Pembelajaran Kooperatif Tipe STAD terhadap kemampuan pemecahan masalah matematika. Teknik pengumpulan data diperoleh dengan cara tes berupa soal uraian dan dokumentasi berupa daftar nama-nama siswa. Instrumen penelitian yang digunakan adalah soal pre-tes dan post-tes sebanyak 3 soal uraian. Teknik analisis data yang digunakan adalah uji normalitas, homogenitas, uji t dengan teknik paired samples $t$-tes dan independent $t$-tes.

Hasil penelitian menunjukkan bahwa, uji paired sample t-tes pada kemampuan pemecahan masalah sebelum dan stelah perlakuan dengan STAD diperoleh nilai rata-rata 50,29 menjadi 83,71 dengan siginifikansi $0,000<0,05$. Artinya bahwa nilai siswa sebelum dan setelah pembelajaran STAD terdapat perbedaan rata-rata kemampuan pemecahan masalah matematika. Berdasarkan hasil uji paired sample t-tes pada kemampuan pemecahan masalah matematika sebelum dan setelah perlakuan menggunakan model pembelajaran konvensional diperoleh nilai rata-rata 44,57 menjadi 75,79 dengan signifikansi $0,000<0,05$. Artinya bahwa ada peningkatan secara signifikan sebelum dan setelah pembelajaran konvensional. Berdasarkan hasil uji independent samples $t$-tes diperoleh nilai rata-rata 83,71 dan 75,79 dengan nilai signifikansi $0,009<0,05$. Artinya bahwa terdapat perbedaan rata-rata kemampuan pemecahan masalah siswa pada pembelajaran STAD dengan siswa pada pembelajaran konvensional. Dapat di simpulkan bahwa model pembelajaran kooperatif tipe STAD berpengaruh terhadap kemampuan pemecahan masalah siswa pada pelajaran matematika.
\end{abstract}

Kata kunci: Pembelajaran Kooperatif Tipe STAD, Kemampuan Pemecahan Masalah Matematika

\section{ABSTRACT}

This study aims to determine the effect of the Type STAD Cooperative Learning model on mathematical problem solving abilities. The data collection technique was obtained by means of a test in the form of description questions and documentation in the form of a list of student names. The research instrument used was 3 pre-test and post-test questions. The data analysis technique used is the normality test, homogeneity, $t$ test with the technique of paired samples t-test and independent $t$-test.

The results showed that, the paired sample t-test on the problem solving ability before and after treatment with STAD obtained an average value of 50.29 to 83.71 with a significance of $0.000<0.05$. This means that the students' scores before and after STAD learning have differences in the average mathematical problem solving abilities. Based on the results of the paired sample t-test on the ability to solve mathematical problems before and after treatment using conventional learning models, the average value was 44.57 to 75.79 with a significance of $0.000<0.05$. This means that there is a significant increase before and after conventional learning. Based on the results of the independent samples $t$-test, the mean values were 83.71 and 75.79 with a significance value of $0.009<0.05$. This means that there is a difference in the average problem-solving ability of students in STAD learning with students in conventional learning. It can be concluded that the STAD type of cooperative learning model has an effect on students' problem solving abilities in mathematics.

Keywords: Cooperative learning STAD Type, Mathematical Problem Solving Skills

\section{PENDAHULUAN}

Pembelajaran matematika mempunyai banyak peran dalam tatanan pendidikan baik tingkat menengah maupun tingkat atas guna mewujudkan manusia Indonesia seutuhnya, yaitu manusia yang mampu 
menyelesaikan permasalahan yang dihadapinya. Hal ini tercantum dalam salah satu tujuan pembelajaran matematika berdasarkan Kurikulum Tingkat Satuan Pendidikan (KTSP) yaitu siswa diharuskan memiliki kemampuan memecahkan masalah di antaranya kemampuan memahami masalah, matematika merencanakan model matematika, menyelesaikan model matematika dan menafsirkan hasil yang telah diperoleh (Dapertemen Pendidikan Nasional, 2006).

Pembelajaran matematika tidak terlepas dari pemecahan masalah yang merupakan aktivitas yang sangat penting, bahkan National Council Of Teacher Of Mathemtics (NCTM) (1980) menyatakan bahwa pemecahan masalah adalah jantung dari pembelajaran matematika (heart of mathematics), hal ini dikarenakan dalam proses pemecahan masalah matematika diperlukan pengetahuan materi matematika. Pengetahuan terkait strategi pemecahan masalah matematika, kontrol diri yang efektif, dan sikap produktif dalam menyikapi dan menyelesaikan masalah tersebut.

Kemampuan pemecahan masalah adalah kemampuan siswa dalam memahami konsep matematis, mencari solusi dan menerapkannya. Dengan adanya kemampuan pemecahan masalah pada diri siswa dapat memudahkan siswa dalam menyelesaikan soal-soal dari tingkat mudah maupun sulit. Kemampuan ini juga dapat membantu siswa dalam mendapatkan hasil yang memuaskan dan dapat mencapai kriteria maksimum. Pemecahan masalah juga dapat dijadikan sebagai tolak ukur keberhasilan siswa selama proses pembelajaran. Menurut Polya (1973) dalam tulisannya menjelaskan masalah matematika terdiri dari dua jenis, yaitu masalah mencari (problem to find) dan masalah membuktikan (problem to prove). Masalah mencari yakni terkait mencari, menentukan, atau mendapatkan nilai objek tertentu yang tidak diketahui dalam soal dan memberi kondisi yang sesuai. Sedangkan masalah membuktikan lebih menekankan pada masalah dengan suatu prosedur dalam menentukan suatu pernyataan benar atau tidak benar.

Kemampuan seseorang dalam pemecahan masalah matematis memerlukan beberapa hal di antaranya kesiapan, kreativitas, pengetahuan serta kemampuan mengaplikasikannya dalam kehidupan sehari-hari. Kemampuan pemecahan masalah matematis harus dimiliki siswa karena dapat memudahkan siswa dalam menyelesaikan masalah dan mendapatkan solusi dari masalah yang dihadapi, baik yang bersumber dari mata pelajaran ataupun masalah yang bersumber dari kehidupan sehari-hari. Siswa dapat dikatakan mampu memecahkan masalah apabila mampu memahami, mencari dan menemukan solusi kemudian menerapkannya dalam kehidupan sehari-hari. Kemampuan pemecahan masalah matematika siswa di Indonesia masih dalam kategori rendah, hal ini dapat dilihat dari hasil UN Mata pelajaran Matematika tingkat SMA/MA sebagaimana Tabel 1.1 berikut.

\begin{tabular}{lcc} 
Tabel 1. Hasil Rata-rata Ujian Nasional Tahun 2019 \\
\multicolumn{1}{c}{ Wilayah } & Rata-Rata \\
& IPA & IPS \\
\hline Nasional & 38,68 & 34,06 \\
NTB & 33,22 & 30,34 \\
Sumbawa & 34,84 & 31,22 \\
MAN 1 Sumbawa & 32,07 & 29,80 \\
\hline \multicolumn{3}{c}{ Sumber: Kemendikbud 2019 }
\end{tabular}

Berdasarkan Tabel 1, nilai rata-rata ujian nasional matematika pada tahun 2019 38,68 untuk jurusan IPA dan 34,06 untuk jurusan IPS. Adapun wilayah NTB nilai rata-rata adalah 33,22 untuk jurusan IPA dan 30,34 untuk jurusan IPS. Begitu juga untuk wilayah Sumbawa 34,84 untuk jurusan IPA dan 31,22 untuk jurusan IPS. Khusus untuk MAN 1 Sumbawa nilai rata-rata 32,07 untuk jurusan IPA dan 29,80 untuk jurusan IPS.

Terdapat banyak faktor yang menjadi penyebab rendahnya kemampuan pemecahan masalah di Indonesia, diantaranya adalah rendah nya pengalaman, Motivasi, bahan ajar yang tidak mendukung siswa untuk mengembangkan kemampuan pemecahan masalah matematika. Berdasarkan hasil observasi yang dilakukan di MAN 1 Sumbawa diperoleh beberapa fakta tentang pembelajaran matematika yang diterapkan guru dikelas, diantaranya: 1) pembelajaran yang dilakukan masih Teacher Center 2) Banyaknya siswa yang tidak memahami, merencanakan, melaksanakan rencana, dan memeriksa kembali hasil dari soal yang diberikan. Adapun hasil angket di MAN 1 Sumbawa tentang sikap siswa terhadap pelajaran matematika 1) kurangnya antusias siswa saat masuk pelajaran matematika. 2) kurang aktifnya siswa dalam bertanya dan menjawab soal 3) tidak adanya keterampilan siswa dalam berpendapat atau mengkritik.

Hal ini terjadi bukan karena siswanya yang tidak menyukai pelajaran tersebut tetapi, strategi yang digunakan masih menggunakan model pembelajaran konvensional. Dimana kita ketahui guru masih menjadikan diri sebagai narasumber yang siswanya hanya menjadi pendengar tanpa adanya timbal balik sesuai dengan pembelajaran yang diharapkan.

Berdasarkan hasil observasi pada pembelajaran matematika dan hasil angket sikap siswa terhadap pembelajaran matematika diperlukannya suatu solusi yang dapat mengatasi masalah belajar siswa. Salah satu solusi yang mampu mengaktifkan siswa dalam pembelajaran, mampu meningkatkan minat siswa terhadap 
pembelajaran matematika, memberikan motivasi dan menarik perhatian siswa dengan memberikan banyak latihan soal yang berbentuk pemecahan masalah. Sehingga pembelajaran bisa berjalan dengan baik dan hasil yang maksimal. Pembelajaran seperti ini salah satunya dengan menggunakan pembelajaran kooperatif tipe STAD.

Pembelajaran kooperatif adalah pelajaran yang dapat memudahkan siswa yang dapat mendorong siswa lebih aktif. Pembelajaran ini juga memberikan kemudahan bagi siswa karena pembelajaran ini membentuk sebuah kelompok kecil sehingga siswa dapat mudah memahami penjelasan dengan teman sebaya khususnya pada pembelajaran tipe STAD (Student Teams Achievment Division). Model pembelajaran kooperatif tipe STAD merupakan salah satu dari banyak model pembelajaran kooperatif yang paling sederhana. Pemebelajaran kooperatif tipe STAD memeliki lima komponen utama yaitu: a) penyajian kelas, b) menetapkan siswa dalam kelompok, c) tes dan kuis, d) skor peningkatan, e) pengakuan kelompok. Komponen-komponen yang ada pada pembelajaran kooperatif tipe STAD mampu mengaktifkan proses pembelajaran dan mendapatkan hasil yang maksimal.

Berdasarkan uraian di atas penulis tertarik untuk mengadakan penelitian yang berjudul "Pengaruh Penerapan Model Pembelajaran Tipe STAD Terhadap Kemampuan Pemecahan Masalah Matematika". Penelitian ini mengkaji pengaruh penerapan pembelajaran kooperatif tipe STAD terhadap kemampuan pemecahan masalah matematika.

\section{Rumusan Masalah}

Merujuk uraian latar belakag masalah tersebut di atas, maka rumusan masalah penelitian ini yakni "Apakah pembelajaran dengan model kooperatif tipe STAD berpengaruh terhadap peningkatan kemampuan pemecahan masalah matematika siswa?"

\section{Tujuan Penelitian}

Berdasarkan rumusan masalah di atas, maka tujuan dari penelitian ini yakni untuk mengetahui "pengaruh pembelajaran dengan model kooperatif tipe STAD terhadap peningkatan kemampuan pemecahan masalah matematika siswa".

\section{METODE PENELITIAN}

Jenis penelitian ini adalah kuasi eksperimen. Pendekatan penelitian yang digunakan adalah pendekatan kuantitatif. Penelitian terdiri dari dua variable yaitu variabel bebas dan variabel terikat. Variabel bebasnya adalah model pembelajaran STAD sedangkan variabel terikatnya adalah kemampuan pemecahan masalah. Penelitian ini dilakukan untuk mengukur kemampuan pemecahan masalah siswa dengan pembelajaran STAD dan kemampuan pemecahan masalah siswa dengan pembelajaran konvensional.

Penelitian dilaksanakan di MAN 1 Sumbawa yang beralamat Jalan Kepiting Gang Santri No 33 Sumbawa Besar, Nusa Tenggara Barat. Penelitian ini di fokuskan pada siswa kelas X IPA Tahun Pelajaran 2019/2020. Penelitian ini di lakukan pada bulan Januari hingga bulan Februari selama 4 minggu (8 pertemuan). Populasi pada penelitian ini adalah seluruh kelas X jurusan IPA MAN 1 Sumbawa. Dalam penentuan sampel dilakukan dengan metode sample random sampling. Ada beberapa sampel yang digunakan dalam penelitian ini sebagai berikut:

a. X IPA 1 sampel yang digunakan sebanyak 28 siswa menggunakan model pembelajaran STAD.

b. X IPA 2 sampel yang digunakan sebanyak 28 siswa menggunakan model pembelajaran Konvensional.

Instrumen berbentuk tes terdiri dari pre-tes kemampuan pemecahan masalah matematika dan post-tes kemampuan pemecahan masalah matematika.

\section{HASIL DAN PEMBAHASAN}

\section{Uji Kesamaan Rata-rata Berpasangan Kemampuan Pemecahan Masalah Sebelum dan Setelah Pembelajaran STAD}

Hasil penelitian melalui uji pengaruh model pembelajaran STAD dengan menggunakan uji kesamaan rata-rata berpasangan kemampuan pemecahan masalah matematika sebelum dan setelah pembelajaran STAD. Adapun uji yang dilakukan sebagai berikut: 
Tabel 2. Hasil Uji Paired Samples Test

\begin{tabular}{cccccccc}
\hline & \multicolumn{4}{c}{ Paired Differences } & & \\
\cline { 3 - 5 } & & Mean & Std. Deviation & Std. Error Mean & T & Df & Sig. (2-tailed) \\
Pair 1 & pretes - posttes & -33.429 & 12.139 & 2.294 & -14.571 & 27 & .000 \\
\hline
\end{tabular}

Berdasarkan Tabel 2, diperoleh informasi bahwa nilai signifikansi 2-tailed $=0,000<0,05$, sehingga $\mathrm{H}_{0}$ ditolak dan $\mathrm{H}_{\mathrm{a}}$ diterima. Artinya bahwa hasil nilai siswa sebelum dan setelah pembelajaran STAD terdapat perbedaan rata-rata kemampuan pemecahan masalah matematika. Maka dibutuhkan uji lanjut dengan melihat nilai rata-rata kemampuan pemecahan masalah siswa sebelum dan setelah pembelajaran STAD sebagaimana Tabel 4.4 berikut:

Tabel 3 Hasil Paired Samples Statistics

\begin{tabular}{lllccc}
\hline & & Mean & N & Std. Deviation & Std. Error Mean \\
\hline Pair 1 & Pretes & 50.29 & 28 & 12.250 & 2.315 \\
& Posttes & 83.71 & 28 & 12.015 & 2.271 \\
\hline
\end{tabular}

Berdasarkan Tabel 3, diperoleh informasi bahwa rata-rata kemampuan pemecahan masalah siswa setelah pembelajaran STAD lebih baik daripada sebelum pembelajaran STAD.Dimana rata-rata setelah pembelajaran STAD adalah 83,71 sedangkan rata-rata sebelum pembelajaran STAD adalah 50,29. Hal ini menunjukkan bahwa terdapat peningkatan yang signifikan adalah 33,42 .

Uji Kesamaan Rata-rata Berpasangan Kemampuan Pemecahan Masalah siswa pada Pembelajaran Konvensional

Tabel 4 Hasil Paired Samples Test

\begin{tabular}{lccccccc}
\hline & \multicolumn{9}{c}{ Paired Differences } & & & \\
\cline { 3 - 4 } & & Mean & Std. Deviation & Std. Error Mean & $\mathrm{T}$ & $\mathrm{df}$ & Sig. (2-tailed) \\
Pair 1 & Pretes - posttes & -31.214 & 12.136 & 2.294 & -13.610 & 27 & .000 \\
\hline
\end{tabular}

Berdasarkan Tabel 4, diperoleh informasi bahwa nilai signifikansi 2-tailed $=0,000<0,05$, sehingga $\mathrm{H}_{0}$ ditolak dan $\mathrm{H}_{\mathrm{a}}$ diterima. Artinya bahwa hasil nilai siswa sebelum dan setelah pembelajaran konvensional terdapat perbedaan rata-rata kemampuan pemecahan masalah matematika. Maka dibutuhkan uji lanjut untuk melihat nilai rata-rata kemampuan pemecahan masalah siswa sebelum dan setelah pembelejaran konvensional sebagaimana Tabel 4.8 berikut:

Tabel 5 Hasil Paired Samples Statistics

\begin{tabular}{llllcc}
\hline & & Mean & N & Std. Deviation & Std. Error Mean \\
\hline Pair 1 & Pretes & 44.57 & 28 & 10.878 & 2.056 \\
& Posttes & 75.79 & 28 & 9.681 & 1.830 \\
\hline
\end{tabular}

Berdasarkan tabel 5, diperoleh informasi bahwa rata-rata kemampuan pemecahan masalah siswa setelah pembelajaran konvensional lebih baik daripada sebelum pembelajaran konvensional. Dimana rata-rata setelah pembelejaran konvensional adalah 75,79 sedangkan sebelum pembelajaran konvensional rata-rata kemampuan pemecahan masalah siswa adalah 44,57. Artinya bahwa ada peningkatan secara signifikan sebelum dan setelah pembelajaran konvensional adalah 31,22.

\section{Uji Kesamaan Rata-rata Kemampuan Pemecahan Masalah Siswa pada Pembelajaran STAD dengan siswa pada Pembelajaran Konvensional}

Tabel 6 Hasil Independent Samples Test

\begin{tabular}{|c|c|c|c|c|c|c|c|c|}
\hline & \multicolumn{3}{|c|}{ Levene's Test for Equality of Variances } & \multicolumn{5}{|c|}{ t-test for Equality of Means } \\
\hline & & & & & & Sig. & $95 \%$ Confidenc & the Difference \\
\hline & & $\mathrm{F}$ & Sig. & $\mathrm{t}$ & df & (2-tailed) & Lower & Upper \\
\hline \multirow[t]{2}{*}{ Hasil } & $\begin{array}{l}\text { Equal variances } \\
\text { assumed }\end{array}$ & 2.049 & .158 & 2.719 & 54 & .009 & 2.082 & 13.775 \\
\hline & $\begin{array}{l}\text { Equal variances not } \\
\text { assumed }\end{array}$ & & & 2.719 & 51.664 & .009 & 2.076 & 13.781 \\
\hline
\end{tabular}


Berdasarkan tabel 6, diperoleh informasi bahwa nilai signifikansi $=0,009<0,05$, sehingga $\mathrm{H}_{0}$ ditolak dan $\mathrm{H}_{\mathrm{a}}$ diterima. Artinya bahwa terdapat perbedaan rata-rata kemampuan pemecahan masalah siswa pada pembelajaran STAD dengan siswa pada pembelajaran konvensional.Maka dibutuhkan uji lanjut dengan melihat rata-rata kemampuan pemecahan masalah siswa sebagai mana pada Tabel 4.11.

Tabel 6 Hasil Group Statistics

\begin{tabular}{llllll}
\hline & Kelas & N & Mean & Std. Deviation & Std. Error Mean \\
\hline \multirow{2}{*}{ Hasil } & Post-Tes STAD & 28 & 83.71 & 12.015 & 2.271 \\
& Post-Tes Konvensional & 28 & 75.79 & 9.681 & 1.830 \\
\hline
\end{tabular}

Berdasarkan tabel 6, diperoleh informasi bahwa nilai rata-rata kemampuan pemecahan masalah siswa pada pembelajaran STAD lebih baik daripada pembelajaran konvensional. Dimana rata-rata kemampuan pemecahan masalah matematika siswa pada pembelajaran konvensional adalah 83,71 sedangkan rata-rata kemampuan pemecahan masalah matematika siswa pada pembeljaran konvensional adalah 75,79.

\section{Pembahasan}

\section{Kemampuan Pemecahan Masalah Siswa pada Pembelajaran STAD}

Berdasarkan hasil uji paired sampel tes diperoleh informasi bahwa rata-rata kemampuan pemecahan masalah siswa sebelum pembelajaran STAD diperoleh hasil 50,29, sehingga dapat diartikan bahwa kemampuan pemecahan masalah matematika masih rendah. Adapun kesulitan yang dialami oleh siswa saat mengerjakan soal adalah siswa tidak mampu menuliskan apa yang diketahui, apa yang di tanyakan serta tidak mampu menuliskan rencana yang akan dilakukan dalam penyelesaian soal yang diberikan. Hal ini terjadi karena kurangnya pemahaman siswa terhadap konsep yang digunakan untuk meneyelesaikan soal-soal. Salah satu upaya untuk meningkatkan kemampuan pemecahan masalah siswa adalah dengan menggunakan pembelajaran STAD.

Setelah adanya pembelajaran STAD selanjutnya hasil siswa di uji dengan uji paired sampel tes diperoleh informasi bahwa rata-rata kemampuan pemecahan masalah siswa adalah 83,71. Artinya bahwa terdapat perbedaan rata-rata kemampuan pemecahan masalah matematika siswa sebelum penerapan pembelajaran STAD dengan rata-rata kemampuan pemecahan masalah matematika siswa setelah penerapan pembelajaran STAD.

Berdasarkan hasil uji paired sampel tes diperoleh informasi bahwa adanya peningkatan rata-rata sebelum dan setelah pembelajaran STAD. Hal ini, di buktikan dengan adanya perbedaan rentang nilai rata-rata yang diperoleh yaitu 33,42. Artinya bahwa, terdapat peningkatan positif terhadap penerapan pembelajaran STAD.

Hal ini dibuktikan dengan penelitian yang telah dilakukan oleh Siregar (2017) yang menyatakan bahwa salah satu faktor yang berpengaruh terhadap kemampuan pemecahan masalah matematika adalah pembelajaran kooperatif khususnya pembelajaran kooperatif STAD. Hal ini dibuktikan dengan hasil pre-tes diperoleh skor terendah 9, skor tertinggi 13, dan rata-rata 11,26. Sedangkan hasil post-tes diperoleh skor terendah 15, skor tertinggi 18 dan rata-rata 15,03. Sehingga dapat dikatakan bahwa dengan menggunakan pembelajaran STAD mampu meningkatkan kemampuan pemecahan masalah matematika siswa.

\section{Perbandingan Kemampuan Pemecahan Masalah Siswa pada Pembelajaran STAD dengan Siswa Pada Pembelajaran Konvensional}

Berdasarkan fakta yang terdapat pada hasil uji independent sample tes diperoleh informasi bahwa nilai rata-rata kemampuan pemecahan masalah matematika siswa pada kelas STAD lebih tinggi di bandingkan dengan nilai rata-rata kemampuan pemecahan masalah siswa pada kelas konvensional. Hal ini dibuktikan dengan hasil tes akhir yang diberikan kepada kedua kelas tersebut dengan perhitungan SPSS 16.0 yaitu 87,71 dan 75,79. Hal ini dikarenakan pada pembelajaran STAD siswa dibentuk kelompok yang terdiri dari 5-6 siswa yang heterogen. Pada pembelajaran STAD ini juga dengan adanya pemberian penghargaan kepada setiap kelompok yang memperoleh nilai tertinggi, sehingga dapat memberikan semangat untuk memperoleh nilai yang lebih baik untuk kelompoknya. Menurut Surya dan Rahayu (2014) bahwa hal ini disebabkan karena dalam pembelajaran kooperatif tipe STAD terdapat belajar kelompok, sehingga siswa dapat bekerja sama dan saling membantu dalam mengatasi kesulitan-kesulitan yang dialaminya selama menyelesaikan permasalahan matematika. Dengan bekerja sama secara kelompok lebih memudahkan siswa untuk mengeluarkan dan memberikan ide-ide sehingga dapat memudahkan penyelesaian masalah. Dengan demikian dapat dikatakan pemahaman siswa terhadap materi pembelajaran matematika menjadi lebih baik.

Pada saat proses pembelajaran STAD dari keempat indikator pemecahan masalah, siswa seringkali kesulitan dalam merencanakan pemecahan masalah. Hal ini dibuktikan dari hasil tes yang diberikan dari 28 
siswa diperoleh kemampuan memahami pemecahan masalah $71,42 \%$, kemampuan siswa merencanakan pemecahan masalah siswa 21,42\%, kemampuan siswa melaksanakan pemecahan masalah siswa 67,85\%, dan kemampuan pemecahan memeriksa kembali $32,14 \%$. Hasil ini menunjukkan bahwa kurangnya pemahaman siswa dalam menggunakan rencana atau langkah-langkah yang akan dilakukan dalam pemecahan masalah

Hal ini juga sejalan dengan penelitian yang dilakukan oleh Wardani (2015) diperoleh kemampuan memahami masalah 83,92\%, kemampuan merencanakan pemecahan masalah 62,5\%, kemampuan siswa melaksanakan pemecahan masalah $65,17 \%$, kemampuan siswa dalam memeriksa kembali $70,59 \%$. Hasil ini membuktikan bahwa kesulitan yang sering dialami siswa adalah siswa tidak mampu merencanakan dan melaksanakan rencana.

\section{PENUTUP}

\section{Simpulan}

Dari hasil penelitian serta pembahasan di atas maka dapat disimpulkan sebagai berikut:

1. Terdapat peningkatan kemampuan pemecahan masalah siswa sebelum dan setelah penerapan pembelajaran STAD.

2. Peningkatan kemampuan pemecahan masalah siswa pada pembelajaran STAD lebih tinggi dari kemampuan pemecahan masalah siswa pada pembelajaran konvensional.

3. Nilai rata-rata kemampuan pemecahan masalah siswa pada pembelajaran STAD lebih tinggi dibandingkan dengan nilai rata-rata kemampuan pemecahan masalah siswa pada pembelajaran konvensional.

4. Berdasarkan beberapa poin di atas di simpulkan bahwa model pembelajaran kooperatif tipe STAD berpengaruh terhadap kemampuan pemecahan masalah siswa pada pelajaran matematika

\section{Saran}

Berdasarkan kesimpulan penelitian yang dilakukan ada beberapa saran yang dikemukakan adalah sebagai berikut:

1. Untuk meningkatkan kemampuan pemecahan masalah matematika siswa salah satu alternatif yang dapat diterapkan oleh guru adalah model pembelajaran kooperatif tipe STAD karena dengan model ini dapat memberikan kesempatan untuk berinteraksi secara aktif dan memudahkan siswa dalam memahami masalah matematika.

2. Bagi peneliti yang akan menerapkan model pembelajaran STAD dibutuhkan waktu yang lebih banyak agar lebih efektif dan berjalan sesuai dengan prosedur mengenai pembelajaran STAD.

3. Bagi peneliti model pembelajaran kooperatif STAD dapat di terapkan ketika menjadi seorang guru sehingga dapat meminimalisir rendahnya kemampuan pemecahan masalah matematika siswa.

\section{DAFTAR PUSTAKA}

Depertemen Pendidikan Nasional. (2006). Standar Isi Kurikulum Tingkat Satuan Pendidikan.

Kemendikbud. (2019). Perbandingan Nilai Per Mata Ujian Siswa Tingkat Nasional, Provinsi, Kabupaten/Kota, dan Sekolah, https://puspendik.kemdikbud.go.id, diakses 11 Juni 2019.

NCTM. (1980). Problem Solving in School Mathematics.Yearbook: NCTM Inc.

Polya, G. (1973). How to Solve it. New Jersey: Princeton University Press.

Siregar, Tanti Jumaisyaroh. (2017). Peningkatan Kemampuan Pemecahan Masalah Matematis Siswa SMP Melalui Pembelajaran Kooperatif Tipe STAD. Jurnal. Medan: UMN Al-Washliyah

Surya, E.,dan Rahayu, R., (2014). Peningkatan Kemampuan Komunikasi dan Pemecahan Masalah Matematis Siswa Ar-Rahman Percut Melalui Pembelajaran Kooperatif Tipe Student Teams Achievement Division (STAD), Jurnal Pendidikan Matematika

Wardani, Damayanti K. (2015) Meningkatkan Kemampuan Pemecahan Masalah dengan Pembelajaran Kooperatif Tipe Student Team Achievement Division. Jurnal Inspiratif. 1(1), 12 